\title{
UJI AKTIVITAS KRIM KULIT DURIAN (Durio zibethinus Murr) TERHADAP BAKTERI Staphylococcus sp. PENYEBAB JERAWAT SECARA In Vitro
}

\author{
Bayu Eka Putra ${ }^{1}$, Randa Mauly Sicha ${ }^{1}$, Sarah Jessica Panggabean ${ }^{1}$ ) \\ ${ }^{1}$ Sekolah Menengah KejuruanAbdurrabPekanbaru, Indonesia \\ email:Randamalysica@gmail.com
}

\begin{abstract}
The use of plants as traditional medicine is still used by people in Indonesia. Apart from being cheap and easy to obtain, traditional medicines derived from plants have side effects that are less dangerous than chemical drugs. The purpose of this study was to determine whether durian skin cream (Durio zibethinus Murr) can inhibit the growth of Staphylococcus Sp. The study was conducted using the experimental laboratory method in vitro. The results showed that durian skin extract obtained from maceration using ethyl acetate solvent used as an active ingredient of anti-acne cream can inhibit the growth of Staphylococcus aureus bacteria with an average of $7.3 \mathrm{~mm}$ and Staphylococcus epidermidis with an average of $11 \mathrm{~mm}$, it can be concluded that durian skin cream has an active substance in the presence of inhibition zone diameter of Staphylococcus aureus bacteria with an average of $7.3 \mathrm{~mm}$ and Staphylococcus epidermidis of $11 \mathrm{~mm}$ and this proves that durian skin cream can be used as an anti-acne drug
\end{abstract}

Keywords: Durian Skin Waste, Cream, Staphylococcus Sp

\begin{abstract}
ABSTRAK
Pemanfaatan tumbuhan sebagai obat tradisional masih dimanfaatkan oleh masyarakat di Indonesia. Selain murah dan mudah didapat, obat tradisional yang berasal dari tumbuhan memiliki efek samping yang tidak kalah berbahaya dibandingkan obat kimia. Tujuan penelitian ini adalah untuk mengetahui apakah krim kulit durian (Durio zibethinus Murr) dapat menghambat pertumbuhan Staphylococcus Sp. Penelitian dilakukan dengan metode eksperimental laboratoris in vitro. Hasil penelitian menunjukkan bahwa ekstrak kulit durian yang diperoleh dari maserasi menggunakan pelarut etil asetat yang digunakan sebagai bahan aktif krim anti jerawat dapat menghambat pertumbuhan bakteri Staphylococcus aureus rata-rata 7,3 mm dan Staphylococcus epidermidis ratarata $11 \mathrm{~mm}$, dapat Dapat disimpulkan bahwa krim kulit durian memiliki zat aktif dengan adanya diameter zona hambat bakteri Staphylococcus aureus rata-rata $7,3 \mathrm{~mm}$ dan Staphylococcus epidermidis $11 \mathrm{~mm}$ dan hal ini membuktikan bahwa krim kulit durian dapat digunakan sebagai obat anti jerawat.
\end{abstract}

Kata Kunci: limbah kulit durian, krim, Staphylococcus $\mathrm{Sp}$ 


\section{PENDAHULUAN}

Pemanfaatan tumbuhan sebagai obat tradisional masih digunakan masyarakat Indonesia, khususnya di daerah pedesaan yang masih kaya dengan keanekaragaman tumbuhannya. Selain mudah didapat dan murah, obat tradisional memiliki efek samping yang jauh lebih rendah tigkat bahayanya dibandingkan dengan obat-obatan kimia.(Sumayyah dan Salsabila, 2017)

Salah satu tumbuhan yang dapat dimanfaatkan sebagai obat tradisional adalah buah durian (Duriozibethinus Murr).Buah durian yang sering dikonsumsi selama ini hanya bagian daging buahnya saja,ternyata jika dilihat kegunaan durian bukan hanya dagingnya yang bisa dimanfaatkan, tetapi juga ditemukan berbagai manfaat dari kulit durian yang sering dibuang, sehingga menjadi sampah yang pada akhirnya membusuk.

Senyawa fitokimia pada tumbuhan yang dapat berkhasiat sebagai antibakteri dan antijamur seperti saponin, tanin, alkaloid, flavonoid, dan tirterpenoid.Senyawa fitokimia yang berasal dari tanaman diketahui merupakan metabolit sekunder tanaman terutama golongan fenolik dan terpen dalam minyak atsiri. Minyak atsiri adalah zat biologis aktif sebagai antibakteri dan antijamur sehingga dapat digunakan sebagai antibotik alami dan bahan pengawet pada makanan (Pratiwi, 2008). Salah satu tanaman yang memiliki senyawa tersebut adalah tanaman buah durian.

Ekstrak etanol kulit durian mengandung saponin, flavonoid, tanin, kuinon,steroid / triterpenoid, dan alkaloid dan menunjukkan hasil uji aktivitas antimikroba sampel kulit Durio zibethinus pada konsentrasi $1 \%$, fraksi paling aktif ditunjukkan pada fraksi etil asetat yang mempunyai diameter hambat paling besar daripada fraksi yang lain dalam uji penghambatan bakteri Staphylococcus aureus dan Escherichia coli) dan jamur Candida albicans(Anggraeni dan Anam, 2016)

Manusia mempunyai berbagai jenis penyakit kulit, salah satunya adalah penyakit jerawat (acne vulgaris). Jerawat merupakan suatu penyakit peradangan pada kulit yang disertai dengan penyumbatan pada saluran kelenjar minyak pada kulit dan rambut (saluran pillosebasea)

Munculnya jerawat pada kulit banyak terdapat pada hidung, dagu, dan dahi. Hal ini di karenakan kelenjar minyak pada area ini lebih banyak (Utami, 2009). Kondisi kulit seperti ini dapat memberikan peluang bagi bakteri anaerobik aerotolerans seperti halnya P. acnes untuk bereproduksi dan menimbulkan jerawat (Djanggola, et al, 2016). Selain itu bakteri penyebab jerawat yaitu bakteri Staphylococcus, bakteri ini bersifat pathogen yang berasal dari kata Staphyle yang artinya buah anggur dan coccus artinya bulat.(Brooks, et al., 2005)

Dalam pengobatan jerawat biasanya menggunakan antibiotik eritromisin, tetrasiklin dan klindamisin.Namun ternyata banyak timbulnya resistensi pada antibiotik tersebut. Berdasarkan penelitian pengujian resistensi antibiotik eritromisin yang telah dilakukan oleh Dreno (2001) menujukkan prevalensi resistensi yaitu 95\% pada bakteri Staphylococcus epidermidis dan 52\% pada Propionibacterium acne dari 40 pasien jerawat(Dreno et al., 2001). Maka dari itu perlu adanya terobosan atau inovasi baru dalam pengobatan jerawat salah satunya dengan obat-obatan yang alami.Dari latar belakang tersebut, penulis tertarik untuk melakukan penelitian uji aktivitas krim kulit durian (Durio zibethinus murr) terhadap bakteriStaphylococcus sp penyebab jerawat

\section{METODE}

\section{Alat dan Bahan}

Alat- alat yang digunakan dalam penelitian ini antara lain vacum rotary evaporator, timbangan analitik, gelas ukur, gelas piala, vortex, elenmeyer, botol ekstrak, tabung reaksi, pipet tetes, pipet volumetrik,lumpang, alu, cawan penguap, beker gelas, sendok spatula, kaca arloji, cawan petri, lidi bakteri, kapas, bunsen, pinset, oven, jangka sorong dan aluminium foil.

Bahan-bahan yang digunakan dalam penelitian ini adalah strain Staphylococcus sp, ekstrak kulit durian (Durio zibethinus Murr)yang di dapatkan di Jalan Arengka Pekanbaru,Emulgid, parafin, Aquadest, kloramfenikol (kontrol positif), Emulgid suspensi bakteri Straphylococus Sp, etil asetat 96\% dan media yang digunakan pada penelitian ini yaitu Muller Hinton Agar (MHA) 


\section{Metode}

1. Pengolahan Sampel

Pengolahan sampel limbah kulit durian terdiri dari beberapa tahapan yaitu pegumpulan limbah kulit durian, disortasi basah,pemisahan kulit dan duri, perajangan, pengeringan dengan oven $\left(60^{\circ} \mathrm{C}\right.$ selama 48 jam $)$, dan disortasi kering

2. Pembuatan Ekstrak Kulit Buah Durian

Sampel kering limbah kulit duriandirendam dengan etil asetat $96 \%$. Kemudian dimaserasi selama 3-4 hari sambil sesekali diaduk. Lalu pelarut diuapkan dengan menggunakan vacum rotary evaporator hingga didapatkan ekstrak kental

3. Pembuatan Krim Kulit Durian

Pembuatan krim kulit durian 10\% diawali dengan pembuatan basis krim sebelum dicampurkan dengan ekstrak kulit durian, adapun formulasi krim kulit durian yang digunakan :

$\begin{array}{ll}\text { R/ Emulgid } & 15 \\ \text { Paraffin Liq } & 15 \\ \text { Ekstrak Kulit Durian } & 10 \\ \text { Aqua dest add } & 100\end{array}$

4. Pengujian Daya Hambat Bakteri

a. Pembuatan Media Potato Dextrose agar

Media MHA yang telah ditimbang 3,8 gram, dimasukkan kedalam labu erlemeyer dan ditambahkan dengan $100 \mathrm{ml}$ aquadestdipanaskan menggukan hotplate sambil diaduk, panaskan hingga larut, tutup dengan kapas, kemudian disterilkan di dalam autoclave selama 15 emnit dengan suhu $121^{\circ} \mathrm{C}$, setelah cukup waktu autoclavedimatikan dan dibiarkan suhu turun, lalu media dikeluarkan dari autoclave dan ditambahkan antibiotik kloramfenikol sebanyak $1 \mathrm{ml}$ sambil dihomogenkan, kemudian dimasukkan ke dalam petridisk steril (Oxoid, 2013)

b. Pembuatan Suspensi Bakteri

Strain bakteri diambil satu ose, kemudian disuspensikan didalam tabung yang berisi $\mathrm{NaCl}$ 0,9\% sterilsampai kekeruhan suspensi sama dengan larutan Mc. Farland (Soemarno, 2001)

c. Penanaman Pada Media Muller Hinton Agar

Kapas lidi steril dicelupkan ke dalam suspensi bakteri yang kekeruhannya telah di standarisasi, tunggu sampai meresap ke dalam kapas. Kemudian kapas lidi di angkat dan diperas dengan menekankan pada dinding tabung bagian dalam sambil diputar. Kemudian goreskan kapas lidi tersebut pada permukaan media Muller Hinton Agar (MHA) dengan memutar cawan petri sampai permukaan media tertutup rapat, lalu media dibiarkan selama 515 menit agar suspense bakteri meresap kedalam agar

d. Pengujian Sampel

Pengujian sampel yaitu dengan penempelan disk pada Muller Hinton Agardilakukan secara manual satu-persatu dengan pinset.Disiapkan krim kulit durian, kontrol positif (kloramfenikol), dan kontrol negatif (Emulgit).Disk kosong diambil dan dicelupkan ke dalam krim kulit durian dan diletakkan pada permukaan media Mueller Hinton Agar yang sudah ditanam Staphylococcus Spdengan sedikit ditekan.Ambil disk kosong dan celupkan ke dalam kloramfenikol(kontrol positif) dan Emulgit (kontrol negatif) dengan menggunakan pinset letakkan pada permukaan media Muller Hinton Agar (MHA) ditanam Staphylococcus Spdengan sedikit ditekan. Pastikan jarak antara disk yang satu dnegan disk yang lain memiliki jarak tidak kurang dari $2 \mathrm{~cm}$.Kemudian inkubasi dalam inkubator selama 2-5 hari pada suhu $30^{\circ} \mathrm{C}$ (Soemarno, 2001)

e. Pembacaan Zona Hambat

Zona hambatan diamati dengan mengamati zona hambat yang terjadi di sekeliling disk dan diukur panjang diameternya dengan jangka sorong. Jika terdapat zona hambat di sekeliling disk, berarti krim kulit durian memiliki kandungan zat aktif sebagai antibakteri terhadap 
StaphylococcusSp.Jika tidak terdapat zona hambatan di sekeliling disk berarti krim kulit durian tidak memiliki kandungan zat aktif sebagai antibakteri terhadap Staphylococcus Sp.

\section{ANALISA DATA}

Data disajikan dalam tabel distribusi frekuensi dan dianalisis secara deskriptif.Analisa data deskriptif dilakukan untuk memperoleh gambaran pada setiap variable dari hasilpenelitian.

\section{HASIL DAN PEMBAHASAN}

Pemanfaatan kulit durian terhadap bakteri Staphylococcus Spdilakukan menggunakan pelarut etil asetat 96\%, kloramfenikol sebagai kontrol positif, kontrol negatif yaitu emulgit. Hasil pengukuran diameter zona hambatan dapat dilihat pada Tabel 1

Tabel I.Hasil Uji Daya Hambat Krim Kulit Durian (Durio zibethinus Murr) Terhadap Pertumbuhan Bakteri Staphylococcus aureus.

\begin{tabular}{|c|c|c|c|c|}
\hline \multirow[b]{2}{*}{ Pengujian } & \multicolumn{3}{|c|}{ Zona Hambatan } & \multirow[b]{2}{*}{ Rata-rata } \\
\hline & $\begin{array}{c}\text { Ulangan } \\
1\end{array}$ & $\begin{array}{c}\text { Ulangan } \\
2\end{array}$ & $\begin{array}{c}\text { Ulangan } \\
\mathbf{3}\end{array}$ & \\
\hline Krim Kulit durian & $8 \mathrm{~mm}$ & $7 \mathrm{~mm}$ & $7 \mathrm{~mm}$ & $7,3 \mathrm{~mm}$ \\
\hline $\begin{array}{l}\text { Basis Cream } \\
\text { (emulgit) (-) }\end{array}$ & $6 \mathrm{~mm}$ & $6 \mathrm{~mm}$ & $6 \mathrm{~mm}$ & $6 \mathrm{~mm}$ \\
\hline kloramfenikol (+) & $20 \mathrm{~mm}$ & $19 \mathrm{~mm}$ & $18 \mathrm{~mm}$ & $19 \mathrm{~mm}$ \\
\hline
\end{tabular}

Berdasarkan tabel I diatas, dapat dilihat zona hambat yang terjadi pada limbah kulit durian memiliki rata-rata 7,3 mm, sedangkan pada kloramfenikol (kontrol positif) memberikan rata-rata sebesar 19 $\mathrm{mm}$ dan pada kontrol negatif tidak terjadi zona hambat (diameter disk $=6 \mathrm{~mm}$ ).

Tabel II. Hasil Uji Daya Hambat Krim Kulit Durian (Durio zibentinus Murr) Terhadap Pertumbuhan BakteriStaphylococcus epidermidis

\begin{tabular}{lcccc}
\hline \multirow{2}{*}{ Pengujian } & \multicolumn{3}{c}{ Zona Hambatan } & \multirow{2}{*}{ Rata-rata } \\
\cline { 2 - 4 } & Ulangan & Ulangan & Ulangan & \\
\hline Krim Kulit durian & $11 \mathrm{~mm}$ & $12 \mathrm{~mm}$ & $10 \mathrm{~mm}$ & $11 \mathrm{~mm}$ \\
$\begin{array}{l}\text { Basis Cream } \\
\text { (emulgit) (-) }\end{array}$ & $6 \mathrm{~mm}$ & $6 \mathrm{~mm}$ & $6 \mathrm{~mm}$ & $6 \mathrm{~mm}$ \\
Kloramfenikol (+) & $17 \mathrm{~mm}$ & $16 \mathrm{~mm}$ & $18 \mathrm{~mm}$ & $17 \mathrm{~mm}$ \\
\hline
\end{tabular}

Penelitian ini menggunakan metodeKirby Bauer yaitu dengan menggunakan disk diffusion. Pada penempelan disk diberi jarak kurang lebih $2 \mathrm{~cm}$, hal ini dimaksudkan agar cakram antibiotik atau sampel dapat berdifusi semaksimal mungkin menghambat bakteri dengan terbentuknya zona bening disekeliling disk (Harmita, 2006)

Berdasarkan penelitian skrining fitokimia yang telah dilakukan pada ekstrak kulit durian menunjukkan bahwa ekstrak kulit durian mengandung senyawa flavonoid, tanin, saponin, fenolik (Setyowati, Hanifah and Nugraheni, 2013) Kandungan senyawa tersebut dapat menghambat pertumbuhan bakteri Staphylococcus sp.

Tingginya kandungan senyawa kimia yang terdapat pada kulit durian yang berperan sebagai anti bakteri yaitu alkaloid, saponin, dan triterpenoid (asam asiatik, asam ursalat) karena kulit durian memiliki sifat kepolaran yang sama dengan etanol yaitu bersifat semipolar hingga polar (Muawanah, Jaudah and Ramadhanti, 2019). Mekanisme senyawa alkaloid terhadap sel bakteri yaitu dengan mengganggu penyusun peptidoglikan sehingga menyebabkan kerusakan pada sel bakteri hal ini 
dikarenakan senyawa alkaloid mengandung nitrogen yang akan bereaksi dengan asam amino yang terdapat pada sel dan DNA bakteri dengan mengubah struktur dan susunannya yang mengakibatkan terjadinya perubahan keseimbangan rantai DNA bakteri sehingga sel bakteri lisis (Arlofa, 2015).

Flavonoid, saponin dan tannin yang terkandung dalam ekstrak kulit durian termasuk ke dalam golongan senyawa fenolik dan saponin yang bersifat larut dalam air dan mengandung gugus fungsi hidroksil (-OH) sehingga mudah masuk ke dalam sel yang membentuk kompleks dengan protein membran sel. Kompleks protein senyawa fenolik terbentuk dengan ikatan lemah, sehingga akan mengalami peruraian kemudian diikuti dengan ikatan penetrasi senyawa fenolik ke dalam sel yang menyebabkan perubahan permeabelitas pada membran, sehingga mengakibatkan lisisnya membran sel bakteri.

Kloramfenikolsebagai kontrol positifdapat menghambat pertumbuhan beberapa golongan bakteri, kloramfenikol merupakan antibakteri, bekerja dengan cara menghambat sintesis protein dan bersifat bakteriostatik.

Berdasarkan penelitian yang telah dilakukan Pratiwi (2008), senyawa fitokimia seperti alkaloid, tanin, saponin, fenolik, flavonoid dan titerpenoid dapat berkhasiat sebagai antibakteri (Pratiwi, 2008). Dan berdasarkan hasil penelitian sebelumnya terhadap ekstrak kulit dan biji buah Lai yang sama sama memiliki kandungan senyawa tersebut mampu menghambat bakteri S.aureus. (Muhsin, 2016).Dengan demikian hasil penelitian uji aktivitas krim kulit durian terhadap bakteri Staphylococcus Sp yang telah dilakukan sesuai dengan teori yang menyatakan bahwa ektrak kulit durian dapat menghambat pertumbuhan bakteri dengan kata lain krim kulit durian bersifat antibakteri.

\section{KESIMPULAN}

Berdasarkan hasil penelitian yang telah dilakukan maka dapat disimpulkan bahwa krim kulit durian (Durio zibethinus Murr), dapat menghambat pertumbuhan Staphylococcus Sp. penyebab jerawat yang dibuktikan dengan terbentuknya zona hambat sebesar 7,3 mm dan $11 \mathrm{~mm}$.

\section{UCAPAN TERIMAKASIH}

Peneliti mengucapkan terimakasih kepada orang tua, guru pembimbing, dan teman-teman yang telah memberikan dukungan dan bantuannya dalam menyelesaikan penelitian ini.

\section{REFERENSI}

Anggraeni, E. V. and Anam, K. 2016. Identifikasi Kandungan Kimia dan Uji Aktivitas Antimikroba Kulit Durian (Durio zibethinus Murr.), Jurnal Kimia Sains dan Aplikasi, 19(3), pp. 87-93. doi: $10.14710 / \mathrm{jksa} \cdot 19.3 .87-93$.

Arlofa, N. 2015. Uji Kandungan Senyawa Fitokimia Kulit Durian sebagai Bahan Aktif Pembuatan Sabun. 1(1), pp. 18-22.

Brooks., 2005. Medical Microbiology, Terjemahan oleh Bagian Mikrobiologi Fakultas Kedokteran Universitas Airlangga. Jakarta: Salemba Medika.

Djanggola, T. N., Yusriadi, Y. and Tandah, M. R. 2016. Formulasi Gel Ekstrak Patikan Kebo (Euphorbia Hirta L.) Dan Uji Aktivitas Terhadap Bakteri Staphylococcus epidermidis.Jurnal Farmasi Galenika (Galenika Journal of Pharmacy) (e-Journal), 2(2), pp. 68-75. doi: 10.22487/j24428744.2016.v2.i2.5954.

Dreno, B. 2001. Erythromycin-resistance of cutaneous bacterial flora in acne.European journal of dermatology: EJD, 11(6), pp. 549-553.

Harmita, D. 2006. Buku Ajar Analisis Hayati, Edisi 3. Jakarta: Buku Kedokteran EGC. 
Muawanah, N., Jaudah, H. and Ramadhanti, T. D. 2019. Pemanfaatan Limbah Kulit Durian Sebagai Anti Bakteri Pada Sabun Transparan.Seminar Nasional Sains dan Teknologi, pp. 1-10.

Muhsin, M. S. 2016. Pemanfaatan Limbah Kulit Buah Lai Durio kutejensis (Hassk) Becc. Sebagai Antibakteri Dari Bakteri Staphylococcus aureus Dan Salmonella enterica Serovar Typhi (S.Typhi)', in Prosiding Seminar Sains dan Teknologi FMIPA Unmul. Samarinda.

Oxoid. 2013. Oxoid and Remel. UK: Oxoid Ltd 2012.

Pratiwi, S. T. 2008. Mikrobiologi Farmasi.Erlangga. Jakarta: Erlangga, pp. 64-74, 205. doi: 10.1016/j.compedu.2013.07.039.

Setyowati, H., Hanifah, H. Z. and Nugraheni, R. P. 2013. Pengobatan Infeksi Jamur Candida albicans. Program Kreativitas Mahasiswa-Penelitian, pp. 1-7.

Soemarno. 2001. Isolasi Dan Identifikasi Fitoaleksin. Yogyakarta: Akademi Analis Kesehatan.

Sumayyah, S. and Salsabila, N. 2017. Khasiat Obat Tradisional Sumayyah 2017.Majalah Farmasetika, 2(5), pp. 2003-2006.

Utami. 2009. Bebas Masalah Kulit. Yogyakarta: Penerbit Kanisius. 